\title{
Ethylene glycol elimination in amine loop for more efficient gas conditioning
}

\author{
Nasibeh Hajilary $^{1 *}$ and Mashallah Rezakazemi²
}

\begin{abstract}
The gas sweetening unit of phase 2 and 3 in South Pars Gas Field (Asalouyeh, Iran) was first simulated to investigate the effect of mono ethylene glycol (MEG) in the amine loop. MEG is commonly injected into the system to avoid hydrate formation while a few amounts of MEG is usually transferred to amine gas sweetening plant. This paper aims to address the points where MEG has negative effects on gas sweetening process and what the practical ways to reduce its effect are. The results showed that in the presence of $25 \%$ of $\mathrm{MEG}$ in amine loop, $\mathrm{H}_{2} \mathrm{~S}$ absorption from the sour gas was increased from 1.09 to $3.78 \mathrm{ppm}$. Also, the reboiler temperature of the regenerator (from 129 to $135^{\circ} \mathrm{C}$ ), amine degradation and required steam and consequently corrosion (1.10 to $17.20 \mathrm{mpy}$ ) were increased. The energy consumption and the amount of amine make-up increase with increasing MEG loading in amine loop. In addition, due to increasing benzene, toluene, ethylbenzene and xylene (BTEX) and heavy hydrocarbon solubility in amine solution, foaming problems were observed. Furthermore, side effects of MEG presence in sulfur recovery unit (SRU) such as more transferring BTEX to SRU and catalyst deactivation were also investigated. The use of total and/or partial fresh MDEA, install insulation and coating on the area with the high potential of corrosion, optimization of operational parameters and reduction of MEG from the source were carried out to solve the problem. The simulated results were in good agreement with industrial findings. From the simulation, it was found that the problem issued by MEG has less effect when MEG concentration in lean amine loop was kept less than 15\% (as such observed in the industrial plant). Furthermore, the allowable limit, source and effects of each contaminant in amine gas sweetening were illustrated.
\end{abstract}

Keywords: $\mathrm{CO}_{2}$ and $\mathrm{H}_{2} \mathrm{~S}$ absorptions, Mono ethylene glycol, Amine gas sweetening, Corrosion, Foaming

\section{Introduction}

Natural gas is produced from wells with a range of impurities and contaminants such as sulfur dioxide $\left(\mathrm{SO}_{2}\right)$, hydrogen sulfide $\left(\mathrm{H}_{2} \mathrm{~S}\right)$ and carbon dioxide $\left(\mathrm{CO}_{2}\right)$ [1-4]. These contaminants should be removed from the natural gas to meet typical specifications for use as commercial fuel or feedstock for natural gas hydrate, liquefied natural gas (LNG) plants, gas turbines, industrial and domestic use [5-8]. Removal of these contaminants is required from point of safety, environmental requirements, corrosion control, product specification, decreasing costs, and

\footnotetext{
*Correspondence: n.hajilari@gu.ac.ir; nasibeh.hajilary@gmail.com ${ }^{1}$ Department of Chemical Engineering, Faculty of Engineering, Golestan University, Gorgan, Iran

Full list of author information is available at the end of the article
}

prevention of catalysts poisoning in downstream facilities [9].

Many methods have been employed to remove acidic components (primarily $\mathrm{H}_{2} \mathrm{~S}$ and $\mathrm{CO}_{2}$ ) from hydrocarbon streams including adsorption, absorption $[10,11]$, membrane [12-16], hybrid system and etc. [17-20]. From these methods, the amine absorption attracts increasing attention due to higher $\mathrm{H}_{2} \mathrm{~S}$ and $\mathrm{CO}_{2}$ removal and environmental compliance. An amine gas treating plant is commonly faced with two major problems: corrosion and instability of operation [6]. Furthermore, the purity of amine has a considerable effect on the efficiency of the gas sweetening unit. In most amine based sour gas treating process, the conventional alkanol amines such as monoethanolamine (MEA), diethanolamine (DEA), methyl diethanolamine (MDEA), disopropanolamine (DIPA), and 
diglycolamine (DGA) is used to separate $\mathrm{H}_{2} \mathrm{~S}$ and $\mathrm{CO}_{2}$ from natural gas $[19,21]$. MDEA is commonly used in industrial plants because it has some advantages over other alkanol amines such as high selectivity to the $\mathrm{H}_{2} \mathrm{~S}$, high equilibrium loading capacity $\left(1 \mathrm{~mol} \mathrm{CO}_{2}\right.$ per $1 \mathrm{~mol}$ amine) and less heat of reaction with $\mathrm{CO}_{2}$, and lower energy consumption in regeneration section.

Mono ethylene glycol (MEG) is commonly injected into the system from two different points (wellhead and gas receiving facilities) as corrosion and hydrate inhibitor especially during winter time when the potential of condensation corrosion and hydrate formation are high. In phases 2 and 3 through the gas path, MEG is injected at sea line, before HIPPS valve, and after the High-pressure separator drum. A few amounts of MEG is usually transferred to the amine gas sweetening plant. The MEG concentration gradually increases in amine gas sweetening plant even to more than 25\%. A large build-up of injection chemicals can eventually lead to fouling and can cause changes in solution physical properties, such as viscosity and mass transfer.

South Pars is a giant gas reservoir shared with Qatar with more than 20 phases. The phases 2 and 3 of South Pars gas refinery has been planted to treat the produced gas through four gas treating trains and stabilize the accompanied condensate from the gas reservoir. Nowadays, about 2500 million standard cubic feet per day (MMSCFD) of gas is fed to this plant. In phases 2 and 3 , the untreated gas is transferred via two $30^{\prime \prime}$ pipelines to onshore facilities for treatment. MEG is transferred by means of two $4^{\prime \prime}$ piggy back lines to the wellhead for hydrate prevention and low dosage hydrate inhibitor (LDHI) is being used as a backup.

The main purpose of the current study is to find where MEG has negative effects on gas sweetening process and what the practical ways to reduce its effect are. The effects of MEG injection on amine gas sweetening and sulfur recovery unit (SRU) units were also studied. Since the presence of MEG was not predicted in the design of gas sweetening unit, it seems the phases 2 and 3 was the first gas plants to deal with this problem. Other gas refineries in South Pars Gas Field which used MEG as a hydrate inhibitor are gradually encountering this problem. Furthermore, a certain value was not found in the literature for the maximum allowable of MEG content in amine loop. To overcome the problems issued by MEG in amine loop, four different methods including: (1) changing operational parameters in the presence of MEG in amine loop; (2) reducing MEG loading in amine loop by total or partial discharging of amine; (3) enhancing resistant to corrosion; (4) developing a strategy to track the source of MEG in amine loop were suggested and investigated.

\section{Gas sweetening unit description}

Phases 2 and 3 of South Pars Gas Field were designed for processing of sour gas by means of four MDEA based amine units (licensed by ELF Aquitaine which does not need to remove all $\mathrm{CO}_{2}$; resulting in high $\mathrm{H}_{2} \mathrm{~S}$ content in acid gas for Claus SRU). The composition of sour gas feed is reported in Table 1. The sour feed gas contains $0.6 \%$ $\mathrm{H}_{2} \mathrm{~S}$ and $2 \% \mathrm{CO}_{2}$.

The objective of the gas treatment unit is to meet the design sweet gas specification which must contain less than 4 ppmv $\mathrm{H}_{2} \mathrm{~S}$ and $1 \mathrm{~mol} \% \mathrm{CO}_{2}$ and produce suitable acid gas for processing in the SRU's. This certain specification of product in industrial plants is commonly achieved through an amine unit including absorption and a regeneration sections. In the absorber, amine solution absorbs $\mathrm{H}_{2} \mathrm{~S}$ and $\mathrm{CO}_{2}$ from the sour gas to produce a sweetened gas stream and a rich amine (a rich amine is an aqueous solution which has absorbed the $\mathrm{H}_{2} \mathrm{~S}$

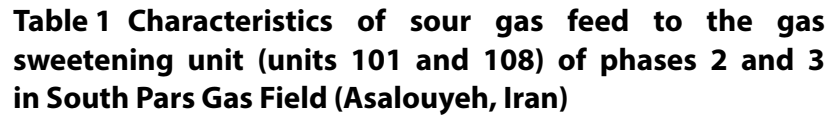

\begin{tabular}{|c|c|}
\hline Components & Mole\% \\
\hline $\mathrm{H}_{2} \mathrm{~S}$ & 0.5548 \\
\hline $\mathrm{CO}_{2}$ & 1.8303 \\
\hline$C_{1}$ & 85.1012 \\
\hline $\mathrm{C}_{2}$ & 5.4372 \\
\hline$C_{3}$ & 1.9888 \\
\hline $\mathrm{i}-\mathrm{C}_{4}$ & 0.368 \\
\hline$n-C_{4}$ & 0.5709 \\
\hline $\mathrm{i}-\mathrm{C}_{5}$ & 0.1766 \\
\hline$n-C_{5}$ & 0.1574 \\
\hline Benzene & 0.0194 \\
\hline $\mathrm{N}_{2}$ & 3.4754 \\
\hline n-hexane & 0.0674 \\
\hline Cyclo hexane & 0.0299 \\
\hline Methyl cyclo pentane & 0.0195 \\
\hline toluene & 0.0046 \\
\hline Methyl cyclo hexane & 0.0094 \\
\hline Heptane & 0.0604 \\
\hline Octane & 0.0324 \\
\hline Ort-xylene & 0.0048 \\
\hline Nonane & 0.003 \\
\hline Decane & 0.0003 \\
\hline Carbonyl sulphide & 0.003 \\
\hline Methyl mercaptans & 0.0021 \\
\hline Ethyl mercaptans & 0.0137 \\
\hline Propyl mercaptans & 0.0037 \\
\hline Butyl mercaptans & 0.0008 \\
\hline Ort-xylene & 0.0048 \\
\hline
\end{tabular}


and $\mathrm{CO}_{2}$ ). The rich amine after passing through a flash drum and increasing its temperature in some exchangers routed into the MDEA regenerator (a stripper with a reboiler) to produce lean amine (a lean amine is a solution regenerated from acid gases) that is come back to the absorber. The stripped acid gas from the regenerator with a high concentration of $\mathrm{H}_{2} \mathrm{~S}$ (more than 30\%) and $\mathrm{CO}_{2}$ (less than 60\%) is routed into a Claus SRU to produce the liquid sulfur. Sweet gas from the absorber is also routed to the dehydration unit. A schematic of phases 2 and 3 of gas sweetening unit is shown in Fig. 1. Chemical reactions take place in the absorber is shown in Eqs. (1 and 2) and the same but opposite take place in the regenerator.

$$
\begin{aligned}
& M D E A+H_{2} S \rightarrow M D E A H^{+} H^{-} \\
& M D E A+H^{+} H_{C O}^{-} \rightarrow M D E A H^{+} H_{3} \rightarrow
\end{aligned}
$$

In this research, the gas sweetening and sulfur recovery units (SRUs) (Units 101 and 108, phases 2 and 3, South Pars Gas Field, Asalouyeh, Iran) were simulated using ProMax (Version 2.3) and Aspen HYSYS (version 7.8), and SULSIM (version 6) simulators and a schematic of the simulations are shown in Fig. 2. The process simulations were used to perform a parametric study to predict the operational parameters change as a function of MEG content in amine loop and also to better identifying of operational conditions. Acidic gases and amines are weak electrolytes, which partially dissociate in the aqueous phase. Hence, electrolyte-NRTL model and SoaveRedlich-Kwong (SRK) equation for thermodynamically modeling of state in Aspen HYSYS were used. Also, "amine sweetening PR" property package and "TSWEET" kinetics model were selected in ProMax to provide complete information about ionic analysis, mass, and molar flow of the streams [22]. The simulated results were in good agreement with industrial findings (Table 2). The properties of MEG are reported in Table 3.

\section{Results and discussion}

\section{Regenerator bottom temperature}

The primary or secondary amines in MDEA solution are commonly formed at higher temperatures because

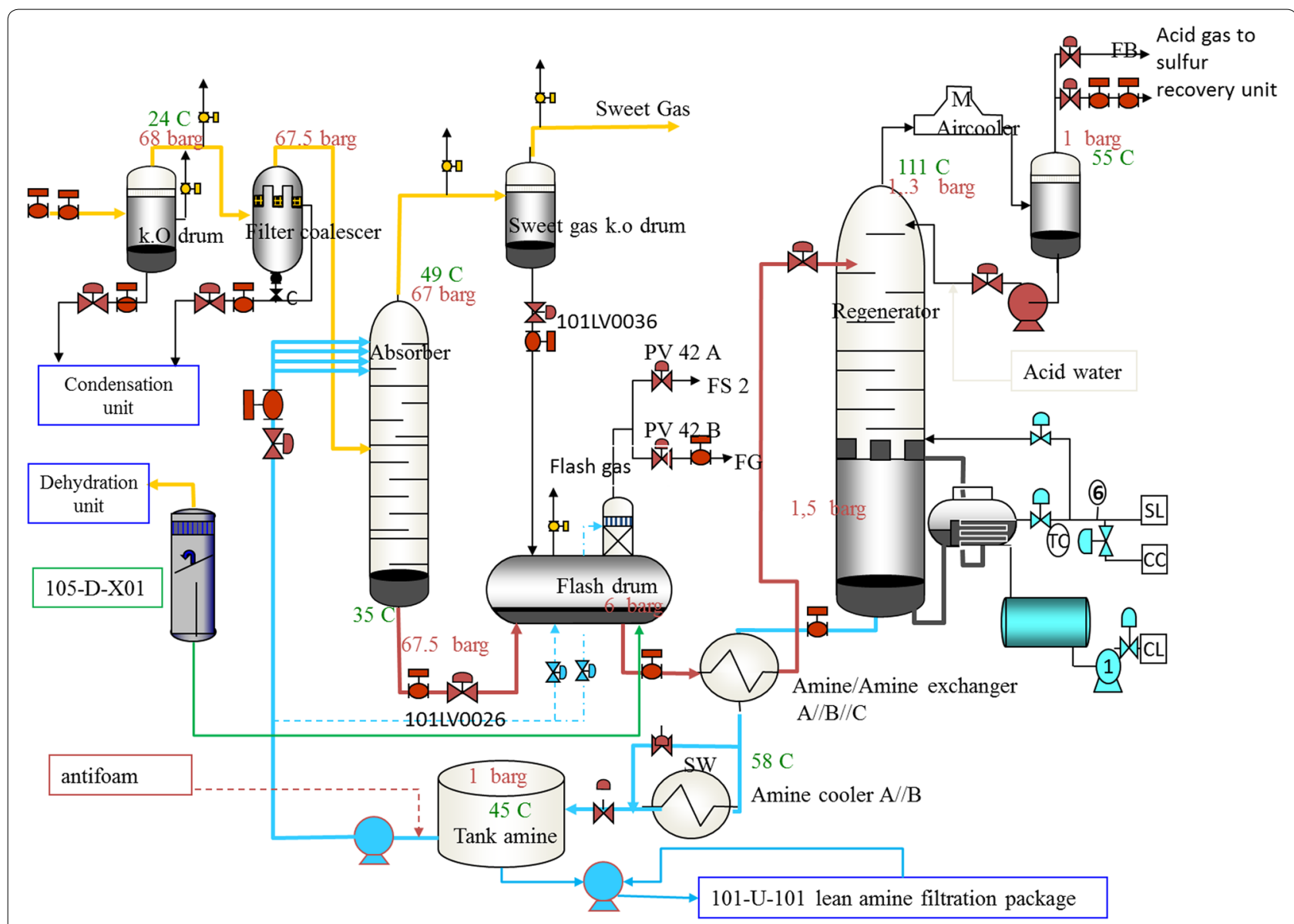

Fig. 1 Schematic of the gas sweetening unit (Unit 101) of phases 2 and 3 in South Pars Gas Field (Asalouyeh, Iran) designed by total company 
a

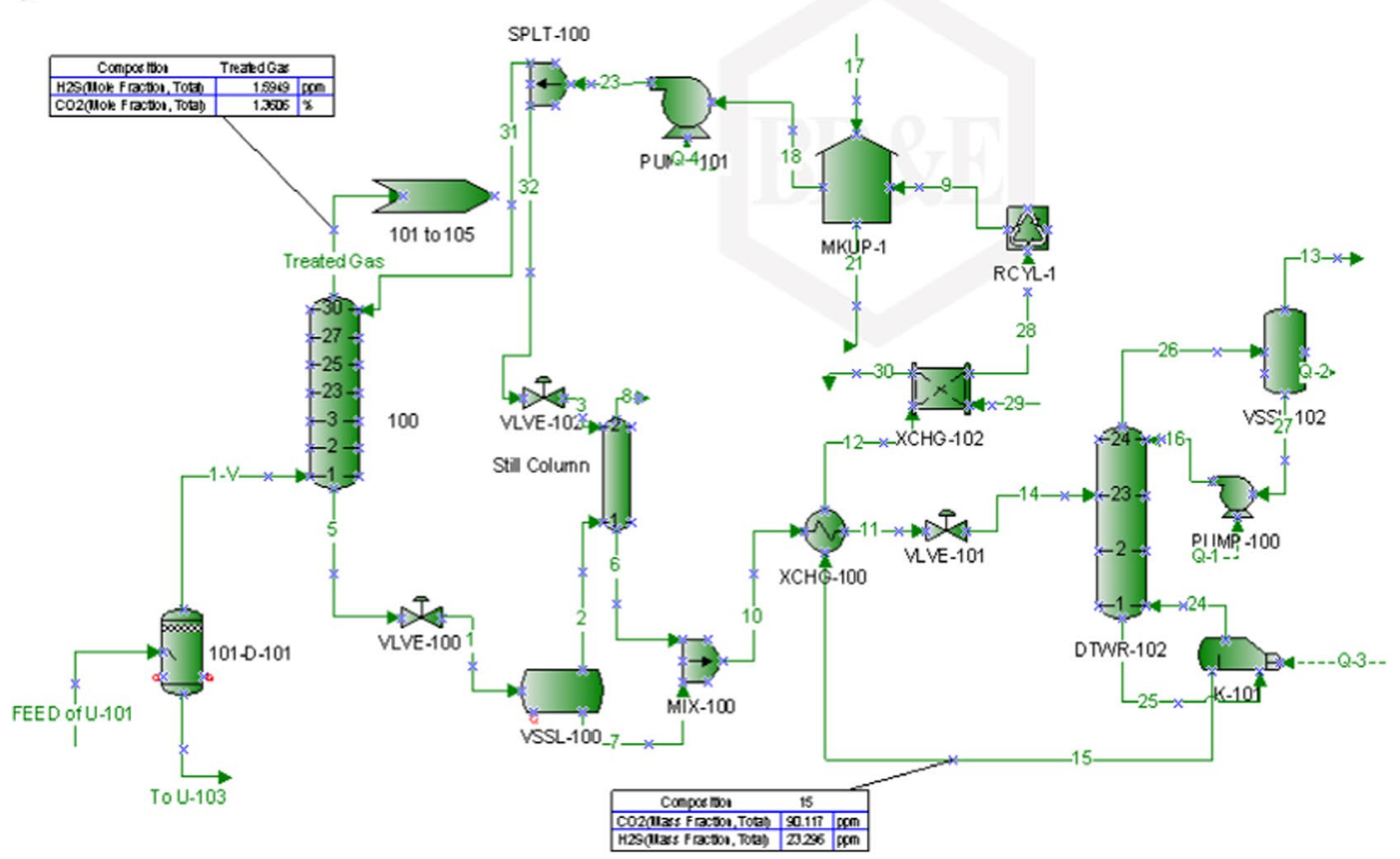

b

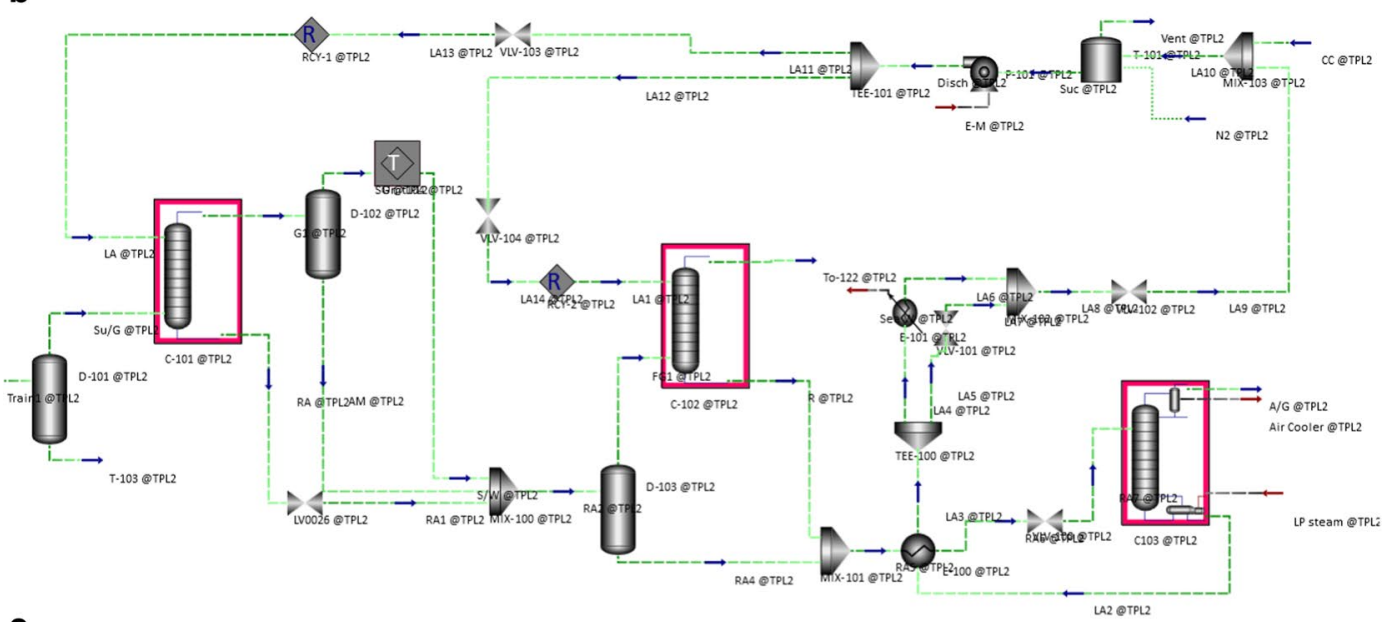

C

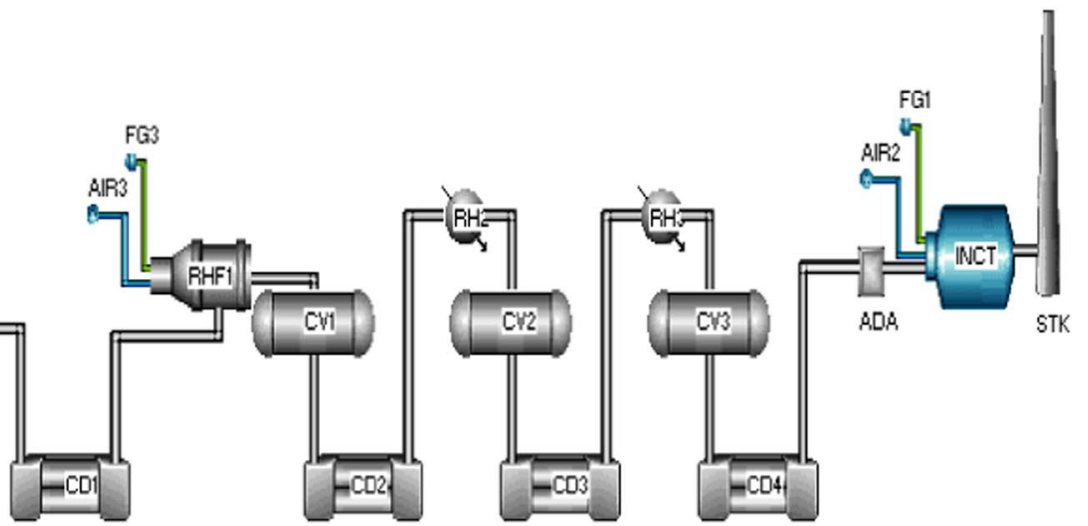

Fig. 2 Schematic of the simulated gas sweetening unit [unit 101 of phases 2 and 3 in South Pars Gas Field (Asalouyeh, Iran)] as from a ProMax, b Aspen HYSYS and c SULSIM software 
Table 2 The comparison of the simulation results of the gas sweetening unit with Promax with actual data

\begin{tabular}{|c|c|c|c|}
\hline Location & Parameters & Simulation results & Actual data \\
\hline \multirow[t]{3}{*}{ Lean amine } & MDEA\% & 45 & 45 \\
\hline & MEG\% & 15 & 15 \\
\hline & Amine flow rate $\left(\mathrm{m}^{3} / \mathrm{h}\right)$ & 155 & 155 \\
\hline Inlet to regenerator & Amine temperature $\left({ }^{\circ} \mathrm{C}\right)$ & 102 & 101.8 \\
\hline \multirow[t]{2}{*}{ Regenerator } & Top temperature $\left({ }^{\circ} \mathrm{C}\right)$ & 100.2 & 100.6 \\
\hline & Bottom temperature $\left({ }^{\circ} \mathrm{C}\right)$ & 134.39 & 132.68 \\
\hline \multirow[t]{4}{*}{ Amine inlet to the regenerator reboiler } & $\mathrm{CO}_{2}$ loading (mol\%) & 0.018 & 0.017 \\
\hline & $\mathrm{H}_{2} \mathrm{~S}$ loading (mol\%) & 0.043 & 0.046 \\
\hline & $\mathrm{H}_{2} \mathrm{~S}$ loading mole/mole amine & 0.0038 & 0.0046 \\
\hline & $\mathrm{CO}_{2}$ loading mole/mole amine & 0.0016 & 0.0018 \\
\hline \multirow[t]{2}{*}{ Gas in the absorber top } & $\mathrm{H}_{2} \mathrm{~S}(\mathrm{ppm})$ & 1.9 & 2.02 \\
\hline & $\mathrm{CO}_{2}(\%)$ & 1.3 & 1.33 \\
\hline \multirow[t]{4}{*}{ Amine in the absorber bottom } & $\mathrm{CO}_{2}$ loading mole/mole amine & 0.11 & 0.12 \\
\hline & $\mathrm{H}_{2} \mathrm{~S}$ loading mole/mole amine & 0.21 & 0.24 \\
\hline & $\mathrm{CO}_{2}(\mathrm{~mol} / \mathrm{h})$ & 67.9 & 67.78 \\
\hline & $\mathrm{H}_{2} \mathrm{~S}(\mathrm{~mol} / \mathrm{h})$ & 129.1 & 129.1 \\
\hline
\end{tabular}

Table 3 Chemical properties of MEG

\begin{tabular}{ll}
\hline Properties & Value \\
\hline Molecular weight $(\mathrm{g} / \mathrm{mol})$ & 62.069 \\
Normal boiling point $\left({ }^{\circ} \mathrm{C}\right)$ & 197.248 \\
Ideal liquid density $\left(\mathrm{kg} / \mathrm{m}^{3}\right)$ & 1110.71 \\
Viscosity @ $60{ }^{\circ} \mathrm{C}(\mathrm{CP})$ & 5.2 \\
Flash point $\left({ }^{\circ} \mathrm{C}\right)$ & 111 \\
\hline
\end{tabular}

MDEA would go through demethylation/dealkylation process [23]. MEA and DEA are formed by replacing alkyl groups with hydrogen atoms in MDEA using the free radical mechanism. Hence, the effect of the regenerator bottom temperature on amine degradation was investigated. Since the various MEG concentrations affect the boiling point of the solution in the system, the variation of boiling temperature of the aqueous solution of MDEA at a $45 \mathrm{wt} \%$ concentration as a function of MEG loading is illustrated in Fig. 3. As can be seen, the boiling point of aqueous MDEA solution increases in presence of MEG content. This boiling point elevation occurs because the boiling point of MEG is higher than that of water, indicating that an MDEA/MEG solution has a higher boiling point than a pure MDEA.

The primary and secondary amines are commonly not selective to $\mathrm{H}_{2} \mathrm{~S}$ and they are more corrosive and need high steam demand for regeneration in compare to MDEA. To prevent primary or secondary amines formation in MDEA solution, the temperature of the reboiler shall not increase more than $132{ }^{\circ} \mathrm{C}$. According to the temperature trends of reboiler (Fig. 4), this

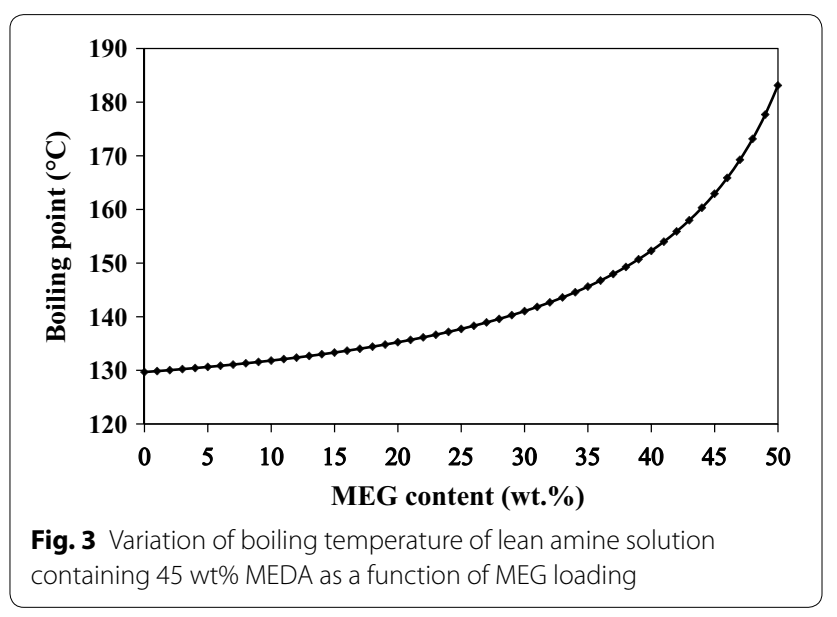

value exceeds frequently and after using fresh amine, the reboiler temperature decreases to the allowable range (less than $130{ }^{\circ} \mathrm{C}$ ). Inducing high temperature degrades amine, produces some acids causing corrosion. Indeed, amine reacts with acids and forms heat stable salts (HSS). This issue may carry out when the stability of salt reduced in the places where some disassociations occur in a site-specific location in the gas sweetening unit. Corrosion takes place when that disassociations form a corrosion cell with metal in the unit. Some issues are also appeared by the chelating effect of the formed acids. The chelating effect is the increased affinity of chelating ligands toward a metal ion in comparison to the affinity of similar non-chelating ligands toward the same ion. However, the chelating effect may 


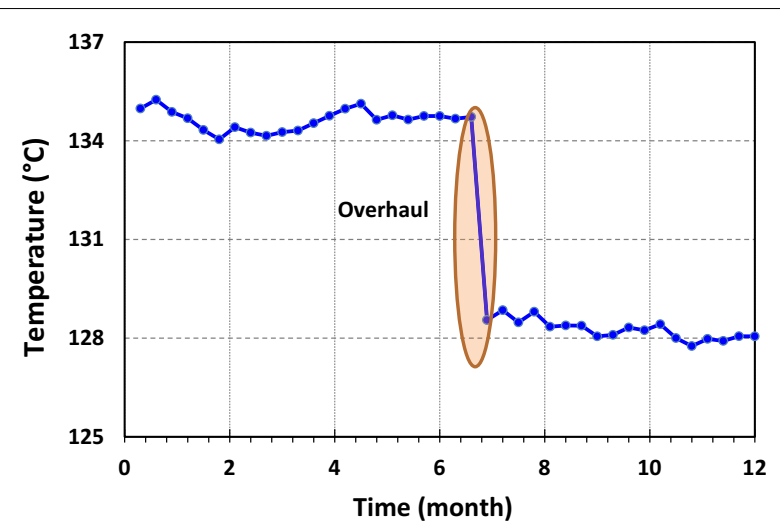

Fig. 4 Regenerator bottom temperature in gas sweetening unit. Overhaul: scheduled shutdown maintenance

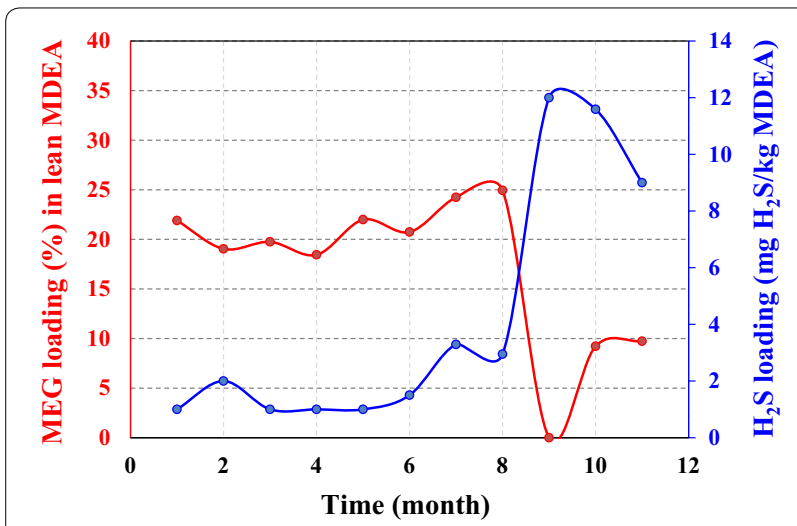

Fig. 5 MEG concentration versus acid gas loading in lean amine solution

keep the iron in the aqueous solution, rather than leading it to create a protective layer on the metal; therefore, acid corrosion occurs and amine degrades [24]. The simulation results also indicated that for the same circulation rate at the same process conditions, when MEG content in amine loop were $0,5,15,0$ and $25 \mathrm{wt} \%$, the regenerator bottom temperatures were 129.6, 130.6, $131.8,133.2,135.2$ and $137.7^{\circ} \mathrm{C}$, respectively. The field data (Fig. 4) confirmed the simulation results.

\section{$\mathrm{H}_{2} \mathrm{~S}$ absorption}

From screening the results presented in Fig. 5, it can be realized that the maximum acid gas loading $\left(12 \mathrm{mg} \mathrm{H}_{2} \mathrm{~S} /\right.$ kg MDEA) occurs at the minimum MEG concentration $(0 \mathrm{wt} \%)$. Actually, the zero value of MEG concentration indicates the used lean amine has become discharged from the tank and the fresh amine is loaded into the tank. In a case, from the field data, the reboiler temperature was $128{ }^{\circ} \mathrm{C}$ with MEG concentrations of $10 \mathrm{wt} \%$ in gas treating trains \#1 and \#2 while in trains \#3 and \#4, the reboiler temperature was $133{ }^{\circ} \mathrm{C}$ with $20 \mathrm{wt} \%$ MEG concentration. As mentioned, to prevent primary or secondary amines formation in MDEA solution, the reboiler temperature shall not exceed $132{ }^{\circ} \mathrm{C}$ [24]. As can be seen, the presence of MEG in the MDEA solution increases the reboiler temperature and decreases the acid gas loading (moles of $\mathrm{CO}_{2}$ and $\mathrm{H}_{2} \mathrm{~S}$ /mole of MDEA) of amine system.

Table 4 shows the simulation results of the gas sweetening unit for five different cases contains 1, 5, 10, 15, 20 and $25 \mathrm{wt} \%$ of MEG in the amine solution. $\mathrm{H}_{2} \mathrm{~S}$ concentration in sweet gas increased from 1.09 to $3.78 \mathrm{ppm}$ as MEG content increased from 1 to $25 \%$ in amine loop. Therefore, the field and simulation results indicated that $\mathrm{H}_{2} \mathrm{~S}$ absorption decreased with increasing the MEG concentration in amine loop. But still, MDEA in presence of MEG was kept $\mathrm{H}_{2} \mathrm{~S}$ selectivity.

The simulation results showed that the energy consumption of regenerator reboiler increases from $39,165,295$ (Case 1) to $41,274,795 \mathrm{~kJ} / \mathrm{h}$ (Case 2). In other equipment, the energy consumption was not changed considerably. Totally, the energy consumption in gas sweetening unit increased $5.4 \%$ in the case of $25 \mathrm{wt} \%$ MEG in lean amine solution while for $1 \mathrm{wt} \%$ MEG, the increase was $0.05 \%$.

\section{$\mathrm{CO}_{2}$ absorption}

The $\mathrm{CO}_{2}$ absorption in MDEA aqueous solution is carried out via two different reaction mechanisms. When $\mathrm{CO}_{2}$ is dissolved in water, the hydrolysis of $\mathrm{CO}_{2}$ is occurred to form carbonic acid, which in turn dissociates slowly to bicarbonate. Finally, the bicarbonate undertakes an acid-base reaction with the amine to yield the overall reaction shown through Eqs. (3) to (6):

Table $4 \mathrm{H}_{2} \mathrm{~S}$ concentration in sweet gas obtained from the simulation for 1 to 25 wt\% MEG content in the amine solution

\begin{tabular}{|c|c|c|c|c|c|c|c|}
\hline Stream & Composition & Case 1 & Case 2 & Case 3 & Case 4 & Case 5 & Case 6 \\
\hline \multirow[t]{3}{*}{ Lean amine } & MEG (\%) & 1 & 5 & 10 & 15 & 20 & 25 \\
\hline & MDEA (\%) & 45 & 45 & 45 & 45 & 45 & 45 \\
\hline & Water (\%) & 54 & 50 & 45 & 40 & 35 & 30 \\
\hline \multirow[t]{2}{*}{ Sweet gas } & $\mathrm{H}_{2} \mathrm{~S}$ (ppm) & 1.09 & 1.26 & 1.74 & 2.02 & 3.12 & 3.78 \\
\hline & $\mathrm{CO}_{2}(\mathrm{ppm})$ & $14,369.89$ & $14,406.39$ & $14,452.50$ & $14,499.18$ & $14,548.98$ & $14,600.70$ \\
\hline
\end{tabular}




$$
\begin{aligned}
& \mathrm{CO}_{2}+\mathrm{H}_{2} \mathrm{O} \leftrightarrow \mathrm{H}_{2} \mathrm{CO}_{3} \text { (Carbonic Acid) } \\
& \mathrm{H}_{2} \mathrm{CO}_{3} \leftrightarrow H^{+}+\mathrm{HCO}_{3} \text { (Bicarbonate) } \\
& \mathrm{H}^{+}+\mathrm{R}_{1} \mathrm{R}_{2} \mathrm{R}_{3} \mathrm{~N} \leftrightarrow \mathrm{R}_{1} \mathrm{R}_{2} \mathrm{R}_{3} \mathrm{NH} \\
& \mathrm{CO}_{2}+\mathrm{H}_{2} \mathrm{O}+\mathrm{R}_{1} \mathrm{R}_{2} \mathrm{R}_{3} \mathrm{~N} \leftrightarrow \mathrm{R}_{1} \mathrm{R}_{2} \mathrm{R}_{3} \mathrm{NH}^{+} \mathrm{HCO}_{3}
\end{aligned}
$$

MDEA reacts with $\mathrm{CO}_{2}$ via the slow $\mathrm{CO}_{2}$ hydrolysis mechanism [24]. $\mathrm{H}_{2} \mathrm{~S}$ reaction with MDEA is fast as compared with the slow $\mathrm{CO}_{2}$ reaction with water to form bicarbonate. So, increasing water concentration may lead to an increase in $\mathrm{CO}_{2}$ reaction with the amine. With increasing MEG content in amine solution, water content decreases and leads to less $\mathrm{CO}_{2}$ absorption from sour gas in the absorber column. It means more $\mathrm{CO}_{2}$ loading in rich amine which must proceed in the regenerator. So, $\mathrm{CO}_{2}$ loading in the acid gas at the top of the regenerator was increased (Table 4) and consequently, the concentration of $\mathrm{H}_{2} \mathrm{~S}$ in SRU feed was increased. The concentration of $\mathrm{H}_{2} \mathrm{~S}$ in SRU feed was increased from 35\% (MEG\% < 15) to 36.5 (MEG\%>24), indicating less $\mathrm{CO}_{2}$ absorption in amine absorber was occurred (Fig. 6).

\section{Corrosion}

Work equipment in south pars refinery is commonly inspected at suitable intervals (12 months). The inspection of the regenerator and reboiler during 36 months showed severe corrosion in different parts of plants including the vapor line of the reboiler, regenerator tower between chimney tray and tray \#7, vapor side of reboiler around the vapor line nozzles, and behind the weir of reboiler. The changes in MEG concentration, HSS, and Fe content in amine loop during 36 months are presented in Figs. 7, 8, 9. As observed, there is a direct relationship between these parameters. Corrosion may cause by HSS through acid evaporation and condensing mechanism in cold spots, as well as, the chelating effect of organic

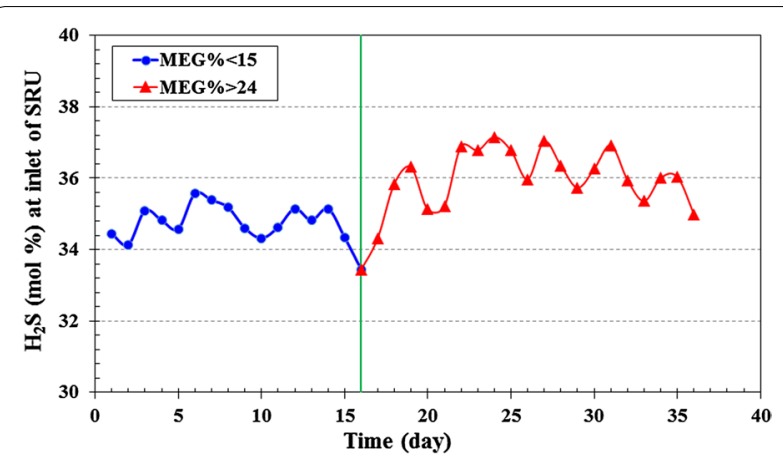

Fig. $6 \mathrm{H}_{2} \mathrm{~S}$ concentration in the inlet of the sulfur recovery unit

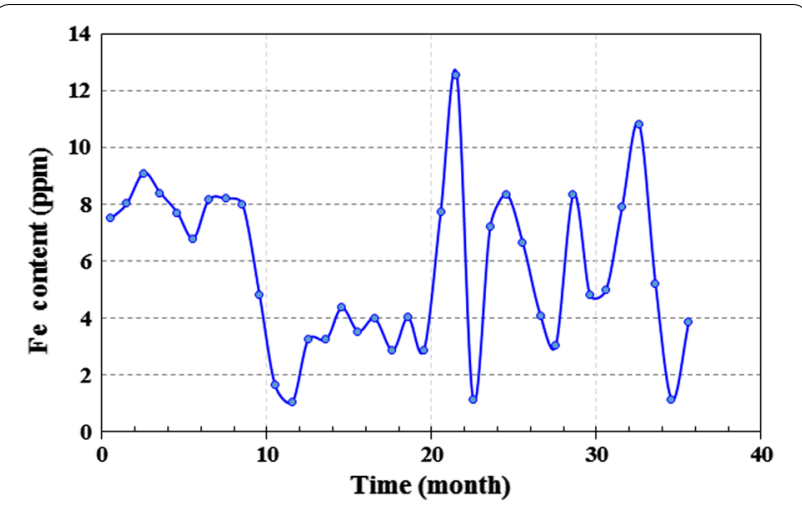

Fig. 7 Total Fe content throughout the 36 months in amine gas sweetening loop

acids and reduction of $\mathrm{pH}$. The high reboiler temperature $\left(131-138{ }^{\circ} \mathrm{C}\right)$ can accelerate the condensation mechanism and acids evaporation. Also, the chemical reaction rate (corrosion) becomes double for every $10{ }^{\circ} \mathrm{C}$ rise in reboiler temperature.

Under thermal conditions, MEG degrades mainly to glycolic acid with oxalic and partially to formic acid. These degradation products promote corrosion by forming iron complexion. In an amine system, similar to HSS, iron complex enhances the corrosion [8]. The corrosion rate in the gas sweetening unit for 20 and 25\% wt $\%$ MEG content was 10.5 and 17.2 mpy, respectively (Fig. 10). It is noted that the refinery's goal is to keep the corrosion rate below $10 \mathrm{mpy}$. The corrosion rate was less than $10 \mathrm{mpy}$ when MEG content was less than $15 \%$. Figure 11 shows a typical example of corrosion observed in amine gas sweetening unit.

\section{BTEX and heavy hydrocarbon solubility}

Benzene, toluene, ethylbenzene, and xylene (BTEX) are aromatic contaminants that can be permanently poisoned the catalyst of Claus SRU. BTEX can reduce SRU process efficiency and increase the operational cost [25]. The BTEX can be absorbed in the amine solution and removed from the flash drum and if not absorbed they are sent to the SRU. According to the simulation results (Table 5), with increasing 25\% MEG content, the solubility of heavy hydrocarbon was increased about $60 \%$. As the amount of BTEX and heavy hydrocarbon were increased, the transferring of these components to the SRU unit was increased. Table 5 shows the content of heavy hydrocarbons in acid gas routed to the SRU. It caused some side effects on SRU performance and leads to sooner catalyst deactivation. A yearly evaluation catalyst was performed in phases 2 and 3 . The results showed that the efficiency of catalyst decreased more than expected. 


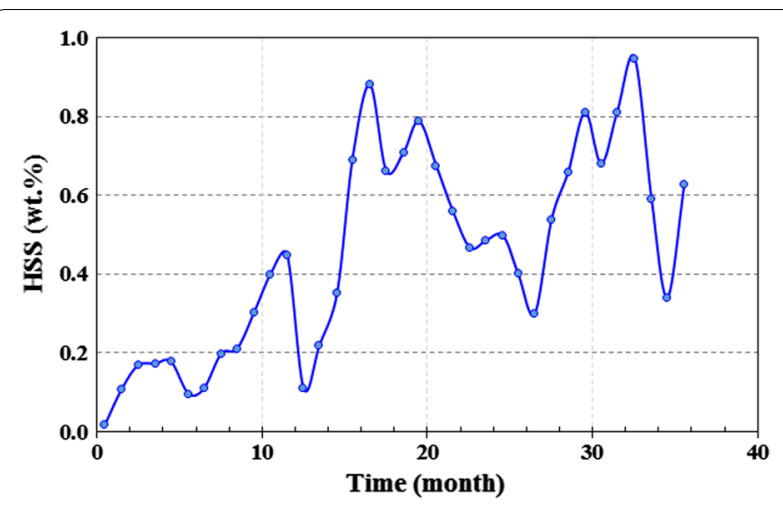

Fig. 8 Heat stable salts (HSS) value throughout the 36 months in amine gas sweetening loop

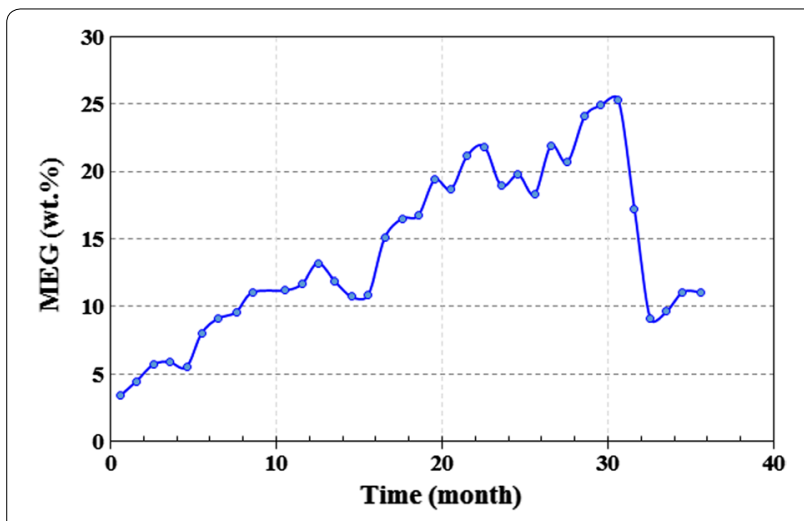

Fig. 9 MEG content throughout the 36 months in amine gas sweetening loop

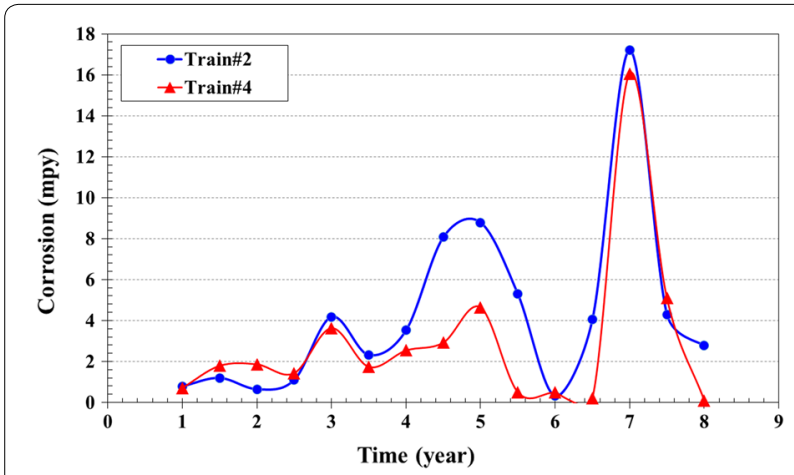

Fig. 10 The corrosion rate of regenerator of MDEA unit trains \#2 and \#4

\section{Foaming}

Foaming in the amine absorber is a common problem. In an industrial plant, the differential pressure (DP) of the absorber, the flow rate of flash gas (gas exited from the flash drum), and the opening of LV0026 [level valve of the bottom of sweet gas Knock-Out (K.O)] are signs of foaming. Parameters such as sour gas inlet temperature, bottom level of absorber, amine flow rate and temperature, gas flow, antifoam concentration, homogeneity and flow rate, lifetime of filters, total suspended solids (TSS) of amine, and lean amine quality have significant effects on foaming formation.

Amine absorber is equipped with DP cells to monitor system abnormalities. As such observed in this plant (Fig. 12), DP of the absorber can be increased up to $0.3 \mathrm{bar}$. When foaming is formed in the absorber, the foam height increases with time, and subsequently, the void volume inside the column reduces, leading to higher pressure drop.

After removing MEG from lean amine, the opening of LV0026 shows amine carryover and DP of absorber were decreased from 0.3 to 0.2 bar (Fig. 12). These signs showed foaming are reduced in amine loop and the used amine has more TSS in compare to the fresh amine.

When there is severe foaming in the absorber, amine carryover from the absorber to sweet gas K.O drum. While other effective parameters were in relatively constant conditions, flash gas and the opening of LV0026 were in a direct relationship with MEG concentration (Fig. 13). The operation signs clearly confirmed excessive foaming with $25 \mathrm{wt} \%$ MEG concentration in amine loop.

\section{MDEA contaminant analysis}

The degradation products, HSS, metals and other contaminants of amine in presence of 25\% MEG were analyzed and the results are reported in Table 6. Furthermore, in this paper, for the first time, all necessary information for academic and industrial users, according to the literatures [24, 26-32] and our industrial experiences, were brought out in a table (Table 5) which contains the allowable limit, source and effects of each contaminant in amine loop and the pros and cons of various operational conditions in amine gas sweetening processes. This information leads users to investigate their own unit circumstance. However, to more evaluation, the composition of used amine was analyzed. The results obtained here showed that the composition of all components are in the allowable range but the composition of acetate in all gas treating units is more than allowable limit (1000 ppm), indicating MEG presence in amine loop.

\section{Operational remedies}

There are numerous operational problems in the gas sweetening unit, especially excessive corrosion. In order to overcome these challenges, some techniques were carried out as follows: 

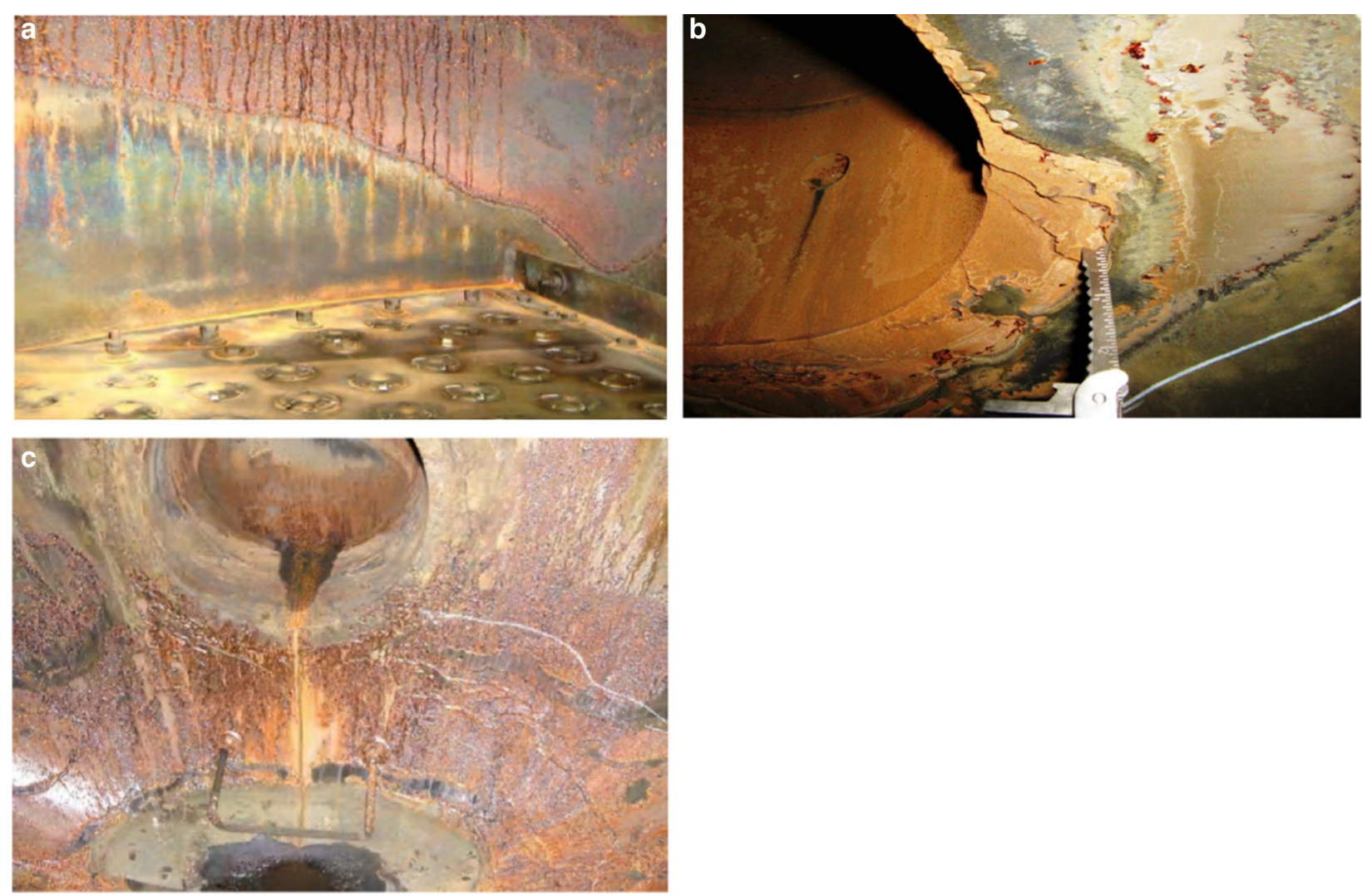

Fig. 11 Corrosion $\mathbf{a}$ in the vapor phase above the normal liquid level through the regenerator tower between chimney tray and tray \#7; $\mathbf{b}$ in vapor side of reboiler around the vapor line nozzles; $\mathbf{c}$ through the reboiler shell of the regenerator behind the baffle

Table 5 Composition of acid gas routed to the SRU with lean amine solution containing 1, 5, 10, 15, 20, and 25 wt\% MEG content

\begin{tabular}{|c|c|c|c|c|c|c|}
\hline $\begin{array}{l}\text { Composition (mole\%)/MEG } \\
\text { (wt\%) }\end{array}$ & $1 \%$ & $5 \%$ & $10 \%$ & $15 \%$ & $20 \%$ & $25 \%$ \\
\hline $\mathrm{iC}_{5}$ & 0.001410 & 0.001586 & 0.001868 & 0.002249 & 0.002779 & 0.003540 \\
\hline $\mathrm{nC}_{5}$ & 0.001769 & 0.001984 & 0.002326 & 0.002786 & 0.003420 & 0.004325 \\
\hline Benzene & 0.067098 & 0.069330 & 0.072688 & 0.076839 & 0.082082 & 0.088810 \\
\hline $\mathrm{nC}_{6}$ & 0.000276 & 0.000311 & 0.000366 & 0.000441 & 0.000544 & 0.000691 \\
\hline Cyclohexane & 0.002220 & 0.002382 & 0.002627 & 0.002936 & 0.003333 & 0.003856 \\
\hline Methylcyclopentane & 0.000540 & 0.000574 & 0.000626 & 0.000692 & 0.000776 & 0.000885 \\
\hline Toluene & 0.016273 & 0.017176 & 0.018544 & 0.020261 & 0.022468 & 0.025371 \\
\hline Methylcyclohexane & 0.000245 & 0.000266 & 0.000297 & 0.000338 & 0.000390 & 0.000461 \\
\hline $\mathrm{nC}_{7}$ & $8.20 \mathrm{E}-05$ & 0.000935 & 0.000112 & 0.000138 & 0.000175 & 0.000229 \\
\hline $\mathrm{nC}_{8}$ & $3.20 \mathrm{E}-05$ & 0.000373 & $4.61 \mathrm{E}-05$ & 0.000586 & 0.000769 & 0.000105 \\
\hline Ortho-xylene & 0.018848 & 0.019907 & 0.021516 & 0.023546 & 0.026170 & 0.029640 \\
\hline $\mathrm{nC}_{9}$ & 0.000829 & 0.000964 & 0.000119 & 0.000149 & 0.000193 & 0.000258 \\
\hline$C_{10}$ & 0.000221 & 0.000263 & 0.000461 & 0.000435 & 0.000583 & 0.000809 \\
\hline
\end{tabular}




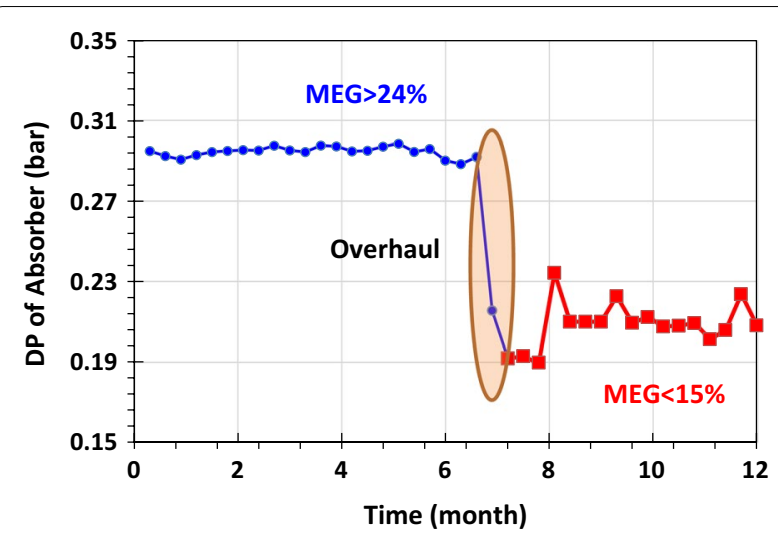

Fig. 12 Differential pressure of amine absorber, overhaul: scheduled shutdown maintenance

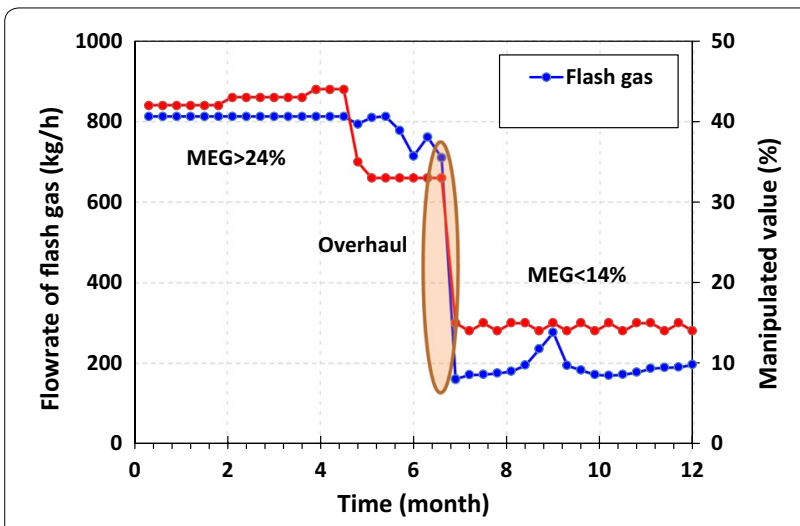

Fig. 13 Flash gas from the flash drum and LV0036 opening overhaul: scheduled shutdown maintenance

- Dropping the bottom temperature of amine regenerator:

In this technique, the temperature and pressure at the top of regenerator must be reduced. The temperature has a positive effect but the pressure has not considerable effect. Moreover, rich amine existed from flash drum is entered to the amine/ amine exchanger and then routed to the regenerator. If the efficiency of amine/amine exchanger increases, the temperature of amine fed to the regenerator will be increased and consequently less steam is needed in the reboiler and the bottom temperature of regenerator can be kept in lower temperature. But from the economical point of view, this technique was not possible.

- Applying a coating of Ceramium on the bottom of the regenerator and around the nozzles of reboiler.

- Applying proper insulation in the corroded area over the vapor line to prevent condensation.
- Changing the material of the vapor line of reboiler from carbon steel to stainless steel-grade 316 (SS316).

- Using partially refreshment of fresh MDEA (0.5 to $5.0 \%)$.

These techniques were effective but not enough. Since there is not any facility for amine purification, it was decided to replace used MDEA with a fresh one and the steps of this operational remedy are pictured in Fig. 14 [33].

After using fresh amine, the $\mathrm{H}_{2} \mathrm{~S}$ content in both fresh amine and consequently in sweet gas were high, indicating acid assisted regeneration phenomena [33]. To reduce $\mathrm{H}_{2} \mathrm{~S}$ loading in amine solution and better amine regeneration, the temperature of amine regenerator was increased from 98 to $110^{\circ} \mathrm{C}$ and the bottom temperature of regenerator was increased according to the temperature at top of the regenerator. It must be emphasized to this point that high bottom temperature can cause amine degradation. To keep regenerator bottom temperature less than $132{ }^{\circ} \mathrm{C}$, the amine flow rate was reduced from 155 to $140 \mathrm{~m}^{3} / \mathrm{h}$. Lower amine flow rate increases MDEA residence time in the regeneration section and as a result, $\mathrm{H}_{2} \mathrm{~S}$ loading decreases. Therefore, the top temperature of regenerator was decreased from 110 to $105{ }^{\circ} \mathrm{C}$ while the bottom temperature was kept less than $132{ }^{\circ} \mathrm{C}$. Since the fresh amine creates some problems in the amine gas sweetening unit, refreshment was partially carried out in order to keep MEG content less than $10 \mathrm{wt} \%$. With results of this experience, it is suggested a few usedamine is added to the fresh amine after the construction of the amine gas sweetening unit.

These solutions were used to reduce the side-effects of MEG. Therefore, it must be found an operational remedy to avoid entering MEG to amine plant. To achieve this purpose and regarding the design, the sweet gas is routed to the gas dehydration unit and is then entered to the K.O drum (105-D-X01, where $\mathrm{X}=1,2,3$, and 4) of dew pointing unit. Bottom of this drum is returned to the amine flash drum. Based on the simulation results, there is a considerable amount of MEG (between 0.5 and $4.0 \mathrm{wt} \%$ ) in the bottom stream of the K.O drum. Table 7 shows the actual and simulated data of MEG\% in this stream.

Therefore, it was decided that this line be routed to the stabilization condensation unit in gas train \#2 (second train) instead of routing to the amine flash drum. The simulation of this plant also indicated that the equilibrium amount of MEG in lean amine is $14 \mathrm{wt} \%$. When the bottom of the K.O drum is not routed to the flash drum and the concentration of MEG in amine loop is more than $14 \mathrm{wt} \%$, the amount of MEG in amine loop decreases. It was found that when the MEG concentration in amine 


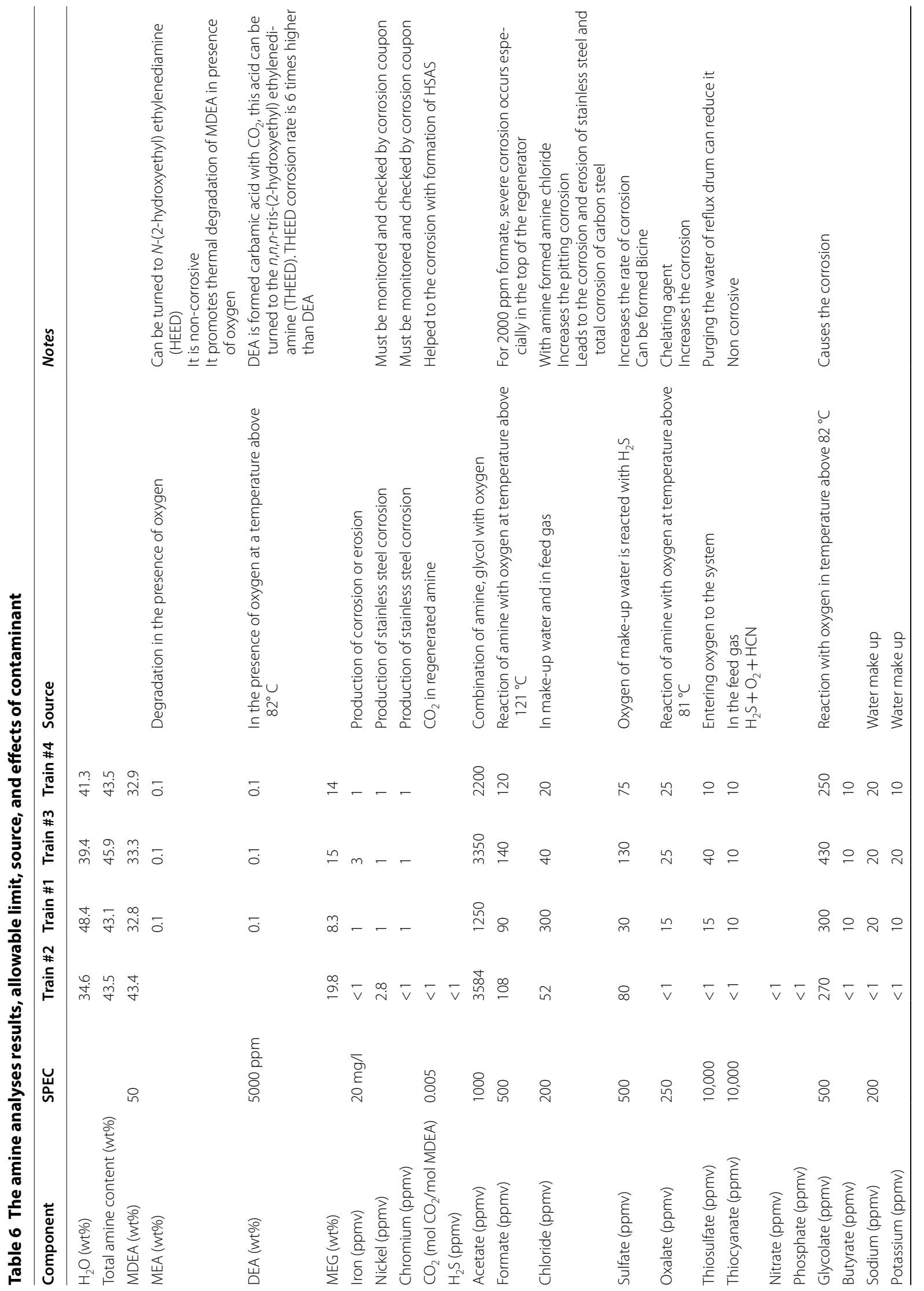




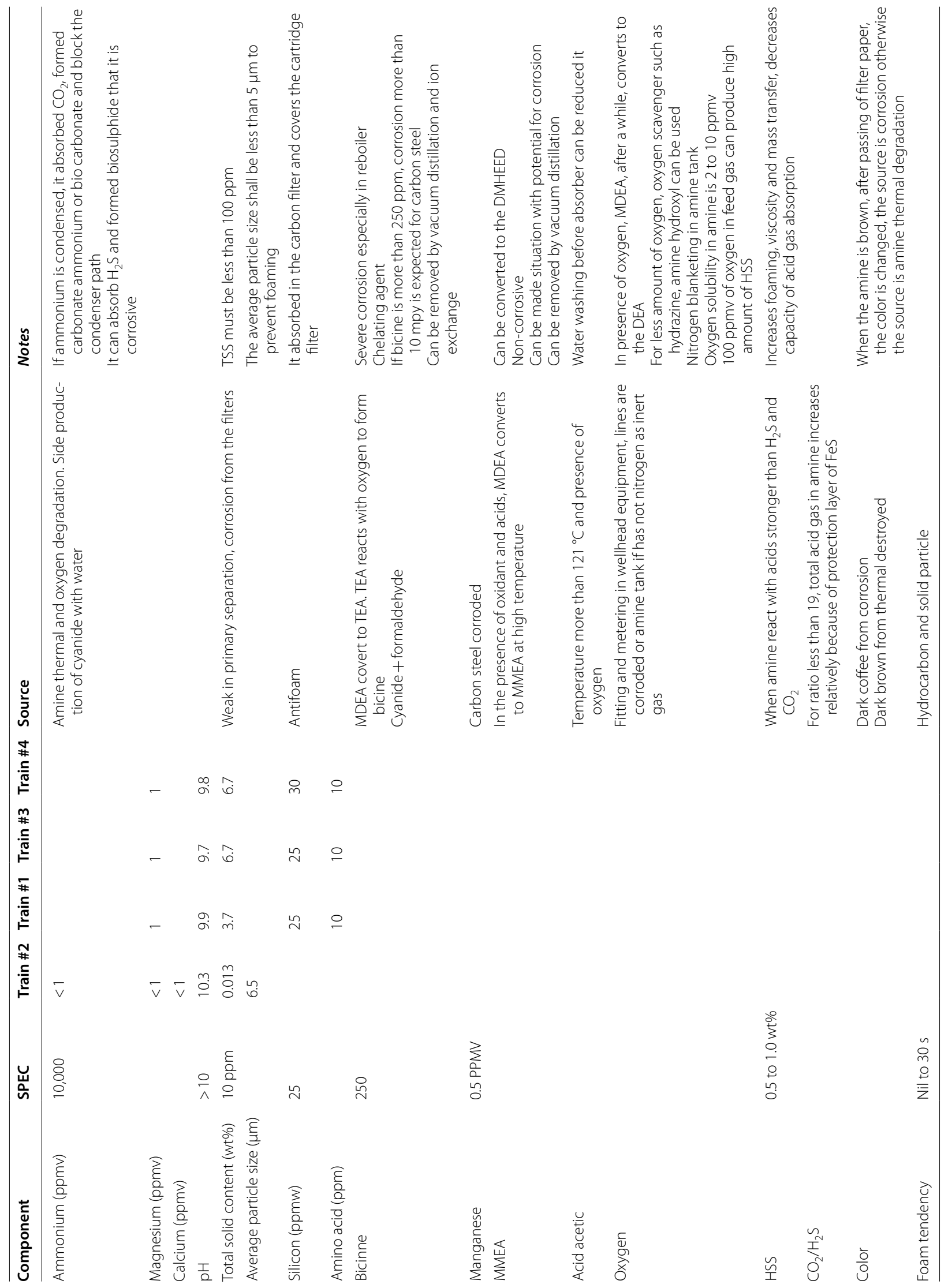




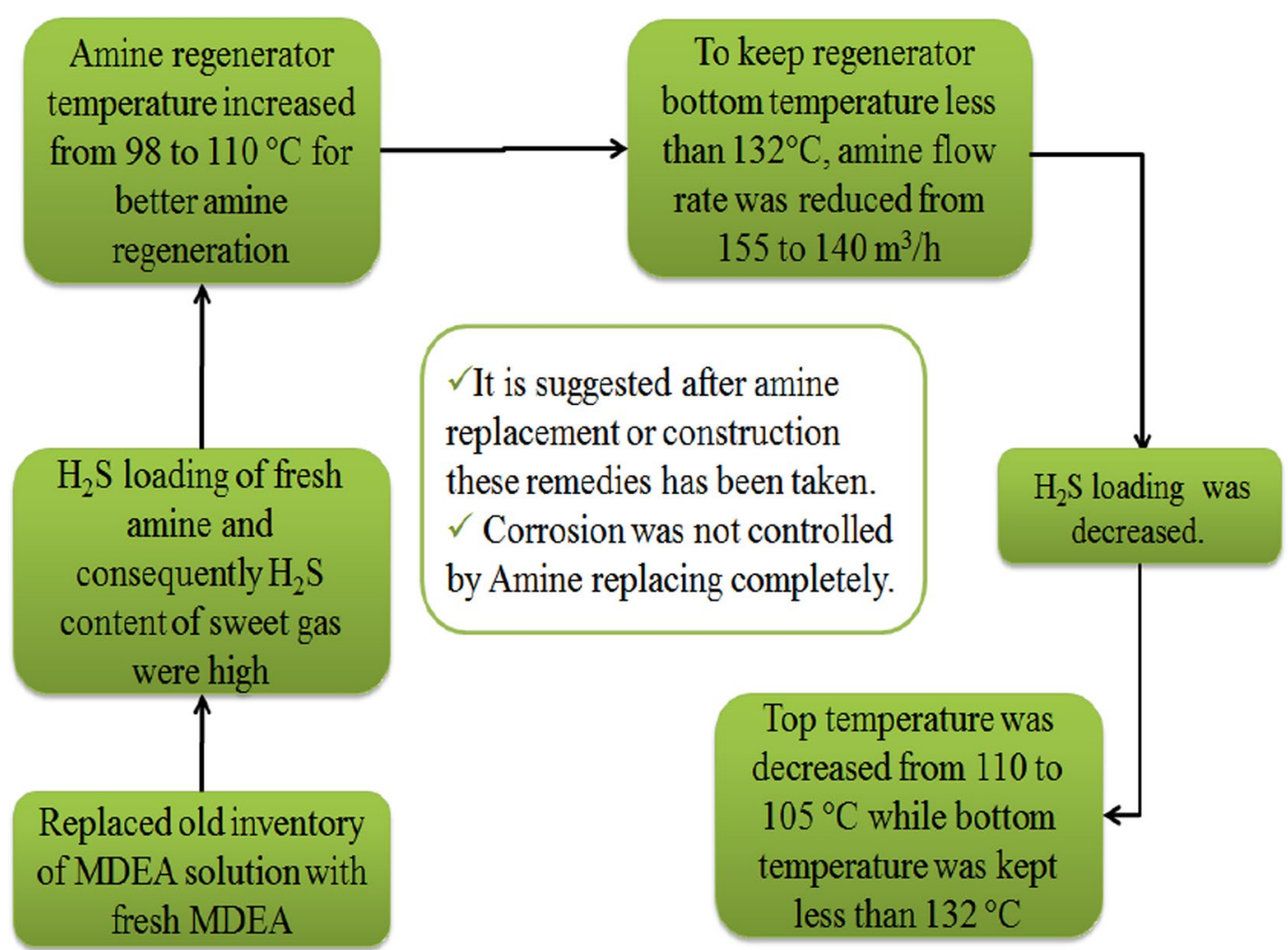

Fig. 14 Operational remedies after total amine replacement

loop is less than $14 \mathrm{wt} \%$, this remedy cannot reduce the MEG loading in amine loop. The MEG loading in lean amine after applying this change is shown in Table 8.

Moreover, increasing amine loss and consequently amine make-up may reduce MEG content in the gas sweetening plant. Hence, the amount of amine make-up was monitored to find whether MEG content in the gas sweetening plant is actually reduced or not. Therefore, the MDEA make-up in different gas treating units was compared (Table 9) indicating normal status in all trains.

In addition, with consideration of operational parameters, this line (bottom of 105-D-X01 routed to the condensation unit) must be checked from the corrosion point of view. Therefore, corrosion coupon was installed in the route. After 6 months, the installed corrosion coupons showed corrosion rate less than 1 mpy (allowable limit of NACE standard RP 0775). Consequently, by applying the proposed operational remedies, the MEG loading in amine loop has kept less than $15 \mathrm{wt} \%$ for 3 years.

\section{Conclusions}

In this paper, the presence of MEG in MDEA loop in phases 2 and 3 of south pars gas field was evaluated. Summary of the findings are presented as follows:
- Introducing $25 \mathrm{wt} \% \mathrm{MEG}$ in amine loop decreases $\mathrm{H}_{2} \mathrm{~S}$ and $\mathrm{CO}_{2}$ absorption from sour gas.

- Introducing $25 \mathrm{wt} \% \mathrm{MEG}$, the regenerator bottom temperature was increased from 129 to $135^{\circ} \mathrm{C}$ and consequently, energy consumption of the sweetening unit was increased 5.4\%.

- Because of less $\mathrm{CO}_{2}$ absorption in absorber column, $\mathrm{H}_{2} \mathrm{~S}$ concentration in inlet SRU was increased. Also, the solubility of BTEX and heavy hydrocarbon in amine solution was increased, which leads to transferring BTEX to SRU and finally sooner catalyst deactivation.

- Foaming problems were increased.

- Severe corrosion was observed in some parts of the regeneration section. Since approximately all the contaminations of amine were in the allowable limit, the reason for the corrosion just can be related to the MEG presence and higher temperature of the regeneration section.

- Total and/or partial refreshment of fresh MDEA was used in gas sweetening unit to reduce MEG content. Furthermore, some techniques (install insulation, coating, etc.) in point of prevention of corrosion were carried out in regenerator tower. 
Table 7 Comparing actual and simulated data of MEG wt\% in the bottom of 105-D-201

\begin{tabular}{llc}
\hline MEG\% in lean amine & \multicolumn{2}{l}{ MEG wt\% in bottom of 105-D-201 } \\
\cline { 2 - 3 } & Simulated & Actual \\
\hline 0 & 0.00 & 0.00 \\
5 & 0.58 & 0.51 \\
10 & 1.22 & 1.22 \\
15 & 1.94 & 1.95 \\
20 & 2.76 & 2.78 \\
25 & 3.71 & 3.73 \\
\hline
\end{tabular}

Table 8 MEG loading in lean amine after routed to the bottom of 105-D-201 in the condensation unit instead of routing to the amine flash drum

\begin{tabular}{llllll}
\hline Month & MEG\% & Month & MEG\% & Month & MEG\% \\
\hline 1 & 26.00 & 13 & 10.09 & 25 & 11.44 \\
2 & 24.20 & 14 & 11.33 & 26 & 11.51 \\
3 & 23.00 & 15 & 11.48 & 27 & 11.87 \\
4 & 19.50 & 16 & 10.62 & 28 & 10.80 \\
5 & 18.80 & 17 & 10.21 & 29 & 11.52 \\
6 & 13.60 & 18 & 10.10 & 30 & 11.14 \\
7 & 15.00 & 19 & 13.10 & 31 & 12.44 \\
8 & 12.20 & 20 & 8.50 & 32 & 10.32 \\
9 & 13.30 & 21 & 9.28 & 33 & 10.64 \\
10 & 11.15 & 22 & 8.49 & 34 & 11.00 \\
11 & 12.01 & 23 & 9.48 & 35 & 14.11 \\
12 & 12.19 & 24 & 9.80 & 36 & 14.10 \\
\hline
\end{tabular}

Table 9 MDEA make-up in gas sweetening unit train \#1 to \#4

\begin{tabular}{lllll}
\hline Train \# & $\mathbf{1}$ & $\mathbf{2}$ & $\mathbf{3}$ & $\mathbf{4}$ \\
\hline MDEA Make-Up $\left(\mathrm{m}^{3}\right)$ & 11.26 & 40.79 & 138.65 & 141.60 \\
\hline
\end{tabular}

- Bottom of the inlet K.O drum of the dew pointing unit (105-D-X01) was routed to the stabilization unit instead of routing to the amine flash drum. Hence, the MEG presence in lean amine was kept less than 15 wt\% until now.

- The value, allowable limit, source and effects of each contaminant and the pros and cons of operational conditions in amine gas sweetening were illustrated.

- It is recommended to consider the effects of MEG in amine loop in the design of gas sweetening unit when glycol exists in the offshore.
Authors' contributions

The work is a product of the intellectual environment of the whole team; and that all members have contributed in various degrees to the analytical methods used, to the research concept, and to the experiment design. Both authors read and approved the final manuscript.

\section{Author details}

${ }^{1}$ Department of Chemical Engineering, Faculty of Engineering, Golestan University, Gorgan, Iran. ${ }^{2}$ Faculty of Chemical and Materials Engineering, Shahrood University of Technology, Shahrood, Iran.

\section{Acknowledgements}

The authors acknowledge the engineering department of Phases 2 and 3 of South Gas Pars.

\section{Competing interests}

The authors declare that they have no competing interests.

\section{Availability of data and materials}

The datasets generated and/or analyzed during the current study are available from the corresponding author on reasonable request.

\section{Consent for publication}

Not applicable.

Ethics approval and consent to participate

Not applicable.

Funding

This research received no specific grant from any funding agency in the public, commercial, or not-for-profit sectors.

\section{Publisher's Note}

Springer Nature remains neutral with regard to jurisdictional claims in published maps and institutional affiliations.

Received: 9 July 2018 Accepted: 15 November 2018

Published online: 23 November 2018

\section{References}

1. Hajilary N, Rezakazemi M (2018) CFD modeling of $\mathrm{CO}_{2}$ capture by water-based nanofluids using hollow fiber membrane contactor. Int J Greenhouse Gas Control 77:88-95

2. Mesbah M, Shahsavari S, Soroush E, Rahaei N, Rezakazemi M (2018) Accurate prediction of miscibility of $\mathrm{CO}_{2}$ and supercritical $\mathrm{CO}_{2}$ in ionic liquids using machine learning. J CO2 Util 25:99-107

3. Dashti A, Riasat Harami H, Rezakazemi M, Shirazian S (2018) Estimating $\mathrm{CH} 4$ and $\mathrm{CO}_{2}$ solubilities in ionic liquids using computational intelligence approaches. J Mol Liq 271:661-669

4. Rezakazemi M, Darabi M, Soroush E, Mesbah M (2019) $\mathrm{CO}_{2}$ absorption enhancement by water-based nanofluids of CNT and $\mathrm{SiO}_{2}$ using hollow-fiber membrane contactor. Sep Purif Technol 210:920-926

5. Mesbah M, Soroush E, Rezakazemi M (2017) Development of a least squares support vector machine model for prediction of natural gas hydrate formation temperature. Chin J Chem Eng 25:1238-1248

6. Fasihi M, Shirazian S, Marjani A, Rezakazemi M (2012) Computational fluid dynamics simulation of transport phenomena in ceramic membranes for $\mathrm{SO}_{2}$ separation. Math Comput Model 56:278-286

7. Shirazian S, Rezakazemi M, Marjani A, Rafivahid MS (2012) Development of a mass transfer model for simulation of sulfur dioxide removal in ceramic membrane contactors. Asia Pac J Chem Eng 7:828-834

8. Rezakazemi M, Ebadi Amooghin A, Montazer-Rahmati MM, Ismail AF, Matsuura T (2014) State-of-the-art membrane based $\mathrm{CO}_{2}$ separation using mixed matrix membranes (MMMs): an overview on current status and future directions. Prog Polym Sci 39:817-861

9. Hajilary N, Shahi A, Rezakazemi M (2018) Evaluation of socio-economic factors on $\mathrm{CO} 2$ emissions in Iran: factorial design and multivariable methods. J Clean Prod 189:108-115 
10. Rezakazemi M, Zhang Z (2018) Desulfurization materials A2. In: Dincer I (ed) Comprehensive energy systems. Elsevier, Oxford, pp 944-979

11. Soroush E, Shahsavari S, Mesbah M, Rezakazemi M, Zhang ZE (2018) A robust predictive tool for estimating $\mathrm{CO}_{2}$ solubility in potassium based amino acid salt solutions. Chin J Chem Eng 26:740-746

12. Rezakazemi M, Sadrzadeh M, Matsuura T (2018) Thermally stable polymers for advanced high-performance gas separation membranes. Prog Energy Combust Sci 66:1-41

13. Sodeifian G, Raji M, Asghari M, Rezakazemi M, Dashti A (2018) Polyurethane-SAPO-34 mixed matrix membrane for $\mathrm{CO}_{2} / \mathrm{CH}_{4}$ and $\mathrm{CO}_{2} / \mathrm{N}_{2}$ separation. Chin J Chem Eng. https://doi.org/10.1016/j.cjche.2018.03.012

14. Zhang Z, Chen F, Rezakazemi M, Zhang W, Lu C, Chang H, Quan X (2018) Modeling of a $\mathrm{CO}_{2}$-piperazine-membrane absorption system. Chem Eng Res Des 131:375-384

15. Rezakazemi M, Vatani A, Mohammadi T (2015) Synergistic interactions between POSS and fumed silica and their effect on the properties of crosslinked PDMS nanocomposite membranes. RSC Adv 5:82460-82470

16. Rezakazemi M, Vatani A, Mohammadi T (2016) Synthesis and gas transport properties of crosslinked poly(dimethylsiloxane) nanocomposite membranes using octatrimethylsiloxy POSS nanoparticles. J Nat Gas Sci Eng 30:10-18

17. Rezakazemi M, Niazi Z, Mirfendereski M, Shirazian S, Mohammadi T, Pak A (2011) CFD simulation of natural gas sweetening in a gas-liquid hollowfiber membrane contactor. Chem Eng J 168:1217-1226

18. Rezakazemi M, Heydari I, Zhang Z (2017) Hybrid systems: combining membrane and absorption technologies leads to more efficient acid gases $\left(\mathrm{CO}_{2}\right.$ and $\left.\mathrm{H}_{2} \mathrm{~S}\right)$ removal from natural gas. J CO2 Util 18:362-369

19. Shirazian S, Marjani A, Rezakazemi M (2012) Separation of $\mathrm{CO}_{2}$ by single and mixed aqueous amine solvents in membrane contactors: fluid flow and mass transfer modeling. Eng Comput 28:189-198

20. Zhang Z, Zhao S, Rezakazemi M, Chen F, Luis P, Bruggen BVD (2017) Effect of flow and module configuration on $\mathrm{SO} 2$ absorption by using membrane contactors. Glob NEST J 19:716-725

21. Razavi SMR, Rezakazemi M, Albadarin AB, Shirazian S (2016) Simulation of $\mathrm{CO}_{2}$ absorption by solution of ammonium ionic liquid in hollow-fiber contactors. Chem Eng Process 108:27-34
22. Berrouk AS, Ochieng R (2014) Improved performance of the naturalgas-sweetening Benfield-HiPure process using process simulation. Fuel Process Technol 127:20-25

23. Lepaumier H, Picq D, Carrette PL (2009) Degradation study of new solvents for $\mathrm{CO}_{2}$ capture in post-combustion. Energy Proc 1:893-900

24. Sheilan MH, Spooner BH, van Hoorn E, Street D, Sames JA (2008) Amine treating and sour water stripping. Amine Experts, Tyler

25. Rahman R, Ibrahim S. A kinetic study on destruction of BTEX and polycyclic aromatic hydrocarbons in Claus Furnace by oxygen enrichment. In: CORROSION 2004, 28 March-1 April 2016, New Orleans, Louisiana.

26. Kakpovbia AE, Mahmood A, Gareau FS, Lee G (2004) A new method for quantifying the risk associated with gas plant operating conditions, Part 2: regenerator section, in: CORROSION 2004, 28 March-1 April. NACE International, New Orleans, Louisiana

27. Rooney PC, DuPart M (2000) Corrosion in alkanolamine plants: causes and minimization, in: CORROSION 2000, 26-31 March. NACE International, Orlando, Florida

28. Pearson H, Dandekar S, Shao J, Norton D. Case study of effects of bicine in $\mathrm{CO}_{2}$ only amine treater service. In: Proceedings of the Laurance Reid gas conditioning conference; 2005. p. 107

29. Abdi MA, Meisen A. Amine degradation: problems: review of research achievements, recovery techniques. In: Proceedings of the 2 nd international oil, gas and petrochemical conference, Tehran, Iran; 2000

30. Carlson S, Canter S, Jenkins J. Canadian gas treating solvent quality control-unique challenges. In: Proceedings of the 2001 sulfur recovery symposium, Canmore, Alberta

31. Howard M, Sargent A (2001) Texas gas plant faces ongoing battle-with oxygen contamination. Oil Gas J 99:52-59

32. Harston J, Ropital F (2007) Amine unit corrosion in refineries, a volume in European Federation of Corrosion (EFC) Series, 1st edn. Elsevier, Amsterdam

33. Hajilary N, Nejad AE, Sheikhaei S, Foroughipour H (2011) Amine gas sweetening system problems arising from amine replacement and solutions to improve system performance. J Pet Sci Technol 1:24-30
Ready to submit your research? Choose BMC and benefit from:

- fast, convenient online submission

- thorough peer review by experienced researchers in your field

- rapid publication on acceptance

- support for research data, including large and complex data types

- gold Open Access which fosters wider collaboration and increased citations

- maximum visibility for your research: over $100 \mathrm{M}$ website views per year

At BMC, research is always in progress.

Learn more biomedcentral.com/submissions 